\title{
GAMBARAN KEJADIAN DIARE PADA ANAK USIA $<2$ TAHUN DI PUSKESMAS KAMPAR KABUPATEN KAMPAR TAHUN 2019
}

\author{
Putri Eka Sudiarti ${ }^{1}$, Salma $^{2}$, Nia Aprilla ${ }^{3}$ \\ ${ }^{1,2,3}$ Program Studi Sarjana Keperawatan Universitas Pahlawan Tuanku Tambusai \\ Putriekasugiarti@gmail.com
}

\begin{abstract}
Abstrak
Diare adalah penyakit yang masih merupakan masalah kesehatan di negara-negara berkembang terutama di Indonesia salah satunya. Tujuan penelitian ini adalah Untuk mengetahui distribusi frekuensi dan klasifikasi kejadian diare pada anak usia $<2$ tahun di Puskesmas Kampar tahun 2019. Metode: Jenis penelitian ini adalah deskriptif, penelitian ini dilakukan di Wilayah Kerja Puskesmas Kampar pada bulan November 2019. Populasi penelitian ini seluruh anak usia <2 tahun yang berkunjung ke Puskesmas Kampar pada bulan Oktober tahun 2019 yang berjumlah 109 orang. Sampel dalam penelitian ini anak usia <2 tahun yang berkunjung ke Puskesmas Kampar sebanyak 52 anak. Teknik pengambilan sampel dalam penelitian ini dengan Teknik Random Sampling dengan menggunakan teknik Accidental Sampling. Alat pengumpulan data yang digunakan dalam penelitian ini adalah berupa lembar ceklist atas kejadian diare. Hasil: anak mengalami diare yaitu sebanyak 28 orang $(53,8 \%)$ dari 52 orang. Anak mengalami kejadian diare dengan dehidrasi ringan yaitu sebanyak 22 orang, dehidrasi Sedang 10 dan dehidarsi berat sedangkan anak yang tidak mengalami dehidrasi berjumlah 18 orang. Kesimpulan: Mayoritas anak mengalami diare yaitu sebanyak 28 orang $(53,8 \%)$. Mayoritas Anak mengalami kejadian diare dengan dehidrasi ringan yaitu sebanyak 22 orang $(42,30 \%)$.
\end{abstract}

Kata Kunci: Anak usia <2 tahun, Diare, Kalasifikasi diare

\begin{abstract}
Diarrhea is a disease that is still a health problem in developing countries, especially in Indonesia, one of them. The purpose of this study was to determine the frequency distribution and classification of diarrhea occurrences in children aged <2 years at the Kampar Health Center in 2019. Methods: This type of research was descriptive, this study was conducted in the Kampar Health Center working area in November 2019. The population of this study were all children. aged $<2$ years who visited the Kampar Puskesmas in October 2019, totaling 109 people. The sample in this study was 52 children aged <2 years who visited the Kampar Health Center. The sampling technique in this study was the random sampling technique using the accidental sampling technique. The data collection tool used in this study was a checklist sheet for the incidence of diarrhea. Results: 28 children (53.8\%) had diarrhea from 52 people. There were 22 children experiencing diarrhea with mild dehydration, 10 moderate dehydration and severe dehydration, while 18 children were not dehydrated. Conclusion: The majority of children experienced diarrhea as many as 28 people (53.8\%). The majority of children experienced diarrhea with mild dehydration as many as 22 people (42.30\%).
\end{abstract}

Keywords: Children aged $<2$ years, Clasification of diarrhea, Diarrhea

\footnotetext{
$\triangle$ Corresponding author :

Address : Ridan Permai

Email : Putriekasugiarti @gmail.com

Phone : 081370359020
} 


\section{PENDAHULUAN}

Diare adalah penyakit yang masih merupakan masalah kesehatan di negara-negara berkembang terutama di Indonesia salah satunya (Kemenkes RI, 2011). Diare adalah buang air besar (BAB) encer atau bahkan dapat berupa air saja (mencret) biasanya lebih dari 3 kali dalam sehari (Ariani, 2016).

Kelompok umur balita adalah kelompok yang paling tinggi menderita diare. Balita rentan terserang penyakit yang disebabkan oleh daya tahan tubuh yang rendah. Resiko tinggi diare terjadi pada anak di bawah usia 2 tahun. Balita yang berumur 12-24 bulan memiliki resiko terjadi diare 2,23 kali dibandingkan anak umur 25-59 bulan (Riset Kesehatan Dasar, 2013).

Menurut World Health Organization (WHO) terjadi sekitar 2 milyar kasus penyakit diare diseluruh dunia setiap tahunnya dan sekitar 1,9 juta anak balita setiap tahunnya meninggal karena penyakit diare. Sebagian besar $78 \%$ terjadi di wilayah Afrika Asia Tenggara. (Kemenkes RI, 2017). Pada Indonesia, diare merupakan penyebab utama kematian pada bayi $31,4 \%$ dan pada balita $25,2 \%$. Sekitar 162.000 balita meninggal akibat diare setiap tahun atau sekitar 460 balita perhari (Kemenkes RI, 2011).

Pada tahun 2018 provinsi Riau memiliki jumlah penderita diare yang dilayani di sarana kesehatan sebesar 30.196 dengan cakupan pelayanan diare 24,23\% (Profil Kesehatan RI, 2017 ). Pada Kabupaten Kampar, tahun 2017 didapatkan sebanyak 1.076 penderita dan kasus tertinggi terjadi di Wilayah Puskesmas Siak Hulu III sebanyak 115 penderita. Sedangkan tahun 2018 sebanyak 10.993 penderita dan kasus tertinggi terjadi di wilayah Puskesmas Kampar sebanyak 884 penderita (Profil kesehatan Kabupaten Kampar, 2017, 2018).

Berdasarkan latar belakang dan penjelasan di atas maka penulis tertarik untuk melakukan penelitian mengenai "Gambaran Kejadian Diare pada Anak Usia < 2 Tahun di Puskesmas Kampar Kabupaten Kampar Tahun 2019”

Tujuan penelitian ini adalah Untuk mengetahui distribusi frekuensi dan klasifikasi kejadian diare pada anak usia < 2 tahun di Puskesmas Kampar tahun 2019.

\section{METODE}

Jenis penelitian ini adalah deskriptif, untuk mengetahui gambaran kejadian diare pada anak <2 tahun di Puskesmas Kampar tahun 2019. dilakukan di Wilayah Kerja Puskesmas Kampar pada bulan November 2019. seluruh anak usia $<2$ tahun yang berkunjung ke Puskesmas Kampar pada bulan Oktober tahun 2019 yang berjumlah 109 orang. Sampel dalam penelitian ini anak usia $<2$ tahun yang berkunjung ke Puskesmas Kampar sebanyak 52 anak.

Teknik pengambilan sampel dalam penelitian ini menggunakan Teknik Random Sampling dengan menggunakan teknik Accidental Sampling. Alat pengumpulan data yang digunakan dalam penelitian ini adalah berupa lembar ceklist atas kejadian diare.. Data yang digunakan dalam penelitian ini adalah data primer, yaitu data yang diperoleh dari puskesmas.

\section{HASIL DAN PEMBAHASAN}

Penelitian ini dilakukan bulan November 2019 di Puskesmas Kampar dengan jumlah responden sebanyak 52 orang sesuai dengan kriteria inklusi dan eksklusi. Hasil yang diperoleh dapat dilihat pada tabel berikut :

1. Kejadian Diare

Tabel 1 Distribusi Frekuensi berdasarkan Kejadian Diare pada Anak Usia < 2 tahun di Puskesmas Kampar Kabupaten Kampar Tahun 2019

\begin{tabular}{lcc}
\hline Kejadian Diare & $\mathbf{f}$ & $\mathbf{( \% )}$ \\
\hline Diare & $\mathbf{2 8}$ & $\mathbf{5 3 , 8}$ \\
Tidak Diare & 24 & 46,2 \\
\hline Total & 52 & 100 \\
\hline
\end{tabular}

Berdasarkan tabel 4.1 diketahui bahwa mayoritas anak mengalami kejadian diare yaitu sebanyak 28 orang $(53,8 \%)$. 


\section{Klasifikasi Diare}

Tabel 2 Distribusi Frekuensi berdasarkan Klasifikaesi Diare pada Anak Usia $<2$ tahun di Puskesmas Kampar Kabupaten Kampar Tahun 2019

\begin{tabular}{ccc}
\hline \multicolumn{1}{c}{ Kejadian Diare } & Frekuensi (f) & Persentase (\%) \\
\hline Diare Tanpa Dehidrasi & 18 & 34,61 \\
Diare dengan Dehidrasi Ringan & 22 & 42,30 \\
Diare dengan Dehidrasi Sedang & 10 & 19,23 \\
Diare dengan Dehidrasi Berat & 2 & 3,84 \\
\hline Total & 52 & 100 \\
\hline
\end{tabular}

Berdasarkan tabel 4.2 diketahui bahwa mayoritas anak mengalami kejadian diare dengan dehidrasi ringan yaitu sebanyak 22 orang $(42,30 \%)$

\section{PEMBAHASAN}

Dari hasil penelitian ini menunjukkan bahwa didapatkan 28 dari 52 anak mengalami diare dan 22 orang anak mnegalami diare dengan dehidrasi ringan hanya 2 anak yang mengalami diare dehidrasi berat. Melihat anggka di atas maka kejadian diare masih tinggi, karena lebih dari setengah responden mengalami diare.

Ada beberapa faktor yang menyebabkan diare diantaranya adalah pemberian ASI tidak ekslusif dan penggunaan botol susu yang tidak benar. Kunci sukses untuk menyusui dengan botol adalah pengaturan dan kebersihan agar menyusui ini praktis dan aman. Kebersihan botol susu pun harus dijaga agar tidak mempermudah pencemaran oleh bakteri dan kuman terutama bakteri dan kuman penyebab diare yang biasa menyerang anak-anak balita terutama anak usia < 2 tahun.

Di negara berkembang seperti Indonesia, $75 \%$ masyarakatnya memberikan susu botol kepada balita. Botol susu yang tidak seril amat berbahaya karena dapat menjadi media berkembang biaknya mikroorganisme pathogen seperti bakteri, virus dan parasit, yang dapat menyebabkan penyakit, salah satunya diare. Hal tersebut juga dikemukakan dalam penelitian Rahayu (2016), yang menyebutkan bahwa sebagian besar ibu kurang memahami kebersihan perawatan botol susu bayi yaitu bagian dalam botol susu serta bagian putting botol. Mereka menganggap bahwa membersihkan botol susu sama seperti membersihkan alat rumah tangga lainnya.
Berdasarkan karakteristik penduduk, kelompok umur balita adalah kelompok yang paling tinggi menderita diare. Balita adalah anak dengan usia dibawah 5 tahun yang memiliki masa pertumbuhan dan perkembangan. Balita sangat rentan terserang penyakit yang disebabkan oleh masih rendahnya daya tahan tubuhnya, salah satunya adalah penyakit diare. Sebagian besar diare terjadi pada anak di bawah usia 2 tahun. Balita yang berumur 12-24 bulan mempunyai resiko terjadi diare 2,23 kali dibandingkan anak umur 25-59 bulan (Riset Kesehatan Dasar, 2013).

\section{SIMPULAN}

Mayoritas anak mengalami diare yaitu sebanyak 28 orang (53,8\%). Mayoritas Anak mengalami kejadian diare dengan dehidrasi ringan yaitu sebanyak 22 orang $(42,30 \%)$.

\section{DAFTAR PUSTAKA}

Ariani, Ayu Putri. Diare Pencegahan dan Pengobatannya. Muaro Bungo: Jambi, 2016.

Pedoman Tatalaksana Diare, 2017.

Profil Kesehatan RI. Kejadian diare. 2017.

Profil Kabupaten Kampar. Kasus kejadian Diare. 2017.

2018. Kejadian Diare. 2018.

Rahayu SA. Hubungan perawatan botol susu dan perilaku mencuci tangan dengan kejadian diare pada batita di wilayah kerja Puskesmas Delanggu. [Naskah Publikasi] Universitas Muhammadiyah Surakarta.2016. diakses dari http://eprints. ums.ac.id/42539/28/NASKAH\%20 PUBLIKASI-sri.pdf

RISKESDAS. Riset Kesehatan Dasar RISKESDAS 2013. Jakarta: Badan Penelitian dan Pengembangan Kesehatan Kementerian Kesehatan RI, 2013. 